\title{
Single Stranded DNA Virus
}

National Cancer Institute

\section{Source}

National Cancer Institute. Single Stranded DNA Virus. NCI Thesaurus. Code C14350.

A virus that has single stranded DNA as its genetic material. 